\title{
QADIMISME VERSUS JADIDISME DAN DINAMIKA ULAMA DI ASIA TENGAH
}

\author{
Ah. Fawaid \\ Sekolah Tinggi Agama Islam Negeri Pamekasan, Indonesia \\ E-mail: fawaid.sjadzili@gmail.com
}

\begin{abstract}
This article attempts to answer two questions: how is the genesis of Islam in Central Asia and how is the dynamics of 'ulama related to the fragmentation of qadimism and jadidism. There is no doubt that 'ulama played important role in spreading Islam and Islamic civilization, including in Central Asia. They got involved in the process of diversification of Islamic teaching and contributed to the struggle against colonialism. However, with modernity the 'ulama underwent fluctuative relation with each other. Diverse responses to modernity resulted in the diversity of ways of actualization in coping with social problems. The rise of jadidism that was reacted by qadimism constituted a modern phenomenon in Central Asia when the ulama attempted to respond modernity. The diversity of ways of actualization caused the relation between qadimism and jadidism problematic. On another occasion, however, the ulama could contribute to each other, especially when they shared the same interest.
\end{abstract}

Keywords: Qadimism; jadidism; Central Asia.

\section{Pendahuluan}

Kajian tentang dinamika Islam di Asia Tengah ${ }^{1}$ tampak kurang mendapatkan perhatian dalam kajian sejarah di tanah air. ${ }^{2}$ Padahal

\footnotetext{
${ }^{1}$ Istilah Asia Tengah dalam tulisan ini, sebagaimana juga dilakukan Ḥasan Aḥmad Maḥmūd, digunakan secara bergantian baik dalam kategori geografis seperti saat ini atau dalam kategori "Islam". Karena konsep Islam tentang Asia Tengah mencakup Iran dan sekitarnya. Ini lantaran Islam yang masuk ke Asia Tengah dalam kategori geografis tidak bisa dilepaskan dari peran Iran sebagai pintu masuknya. Hasan Aḥmad Maḥmūd, al-Islām fì Ásiyà al-Wustāa: bayn al-Fathayn al-'Arabì wa al-Turkì (Kairo: al-Hay’ah al-Mișrīyah al-‘Āmmah lī al-Kitāb, 1973), 8.

2 Pahl menjelaskan bahwa Asia Tengah nyaris hilang di antara negara-negara tentangganya: Rusia di utara; Iran, Afghanistas, dan Pakistra di selatan; Cina di timur; dan Laut Kaspia di Barat. Pengabaian tentang negara-negara di Asia Tengah
} 
peran wilayah "jalur sutra" perdagangan dan dakwah di masa lampau tersebut berkontribusi cukup signifikan dalam perkembangan Islam di kemudian hari di wilayah yang menjadi titik singgung antara Asia di satu sisi dan Afrika serta Eropa di sisi yang lain.

Signifikansi peran tersebut dapat ditelisik, salah satunya, dengan fakta bahwa kehadiran Islam di wilayah ini relatif awal, sehingga tidak aneh bila di wilayah ini bermunculan para ulama terkemuka dengan sumbangan karya yang luar biasa. Sayangnya, dokumentasi tentang peran mereka dalam dakwah Islam tertutupi lantaran dinamika politik yang tidak menguntungkan masyarakat Muslim di wilayah Asia Tengah tersebut. ${ }^{3}$ Padahal Asia Tengah bisa dikatakan sebagai lahan subur lahirnya pemikir Islam yang luar biasa pada masanya hingga saat ini. Sebut saja misalnya Ibn Sīnā, al-Taftazānī, al-Bukhārī, Muḥammad b. Mūsā al-Khawarizmī, Ibn Hạjjāj al-Qushayrī, termasuk juga munculnya ordo sufi terkemuka, yaitu al-Naqshabandīyah. ${ }^{4}$

Dalam sejarahnya, Asia Tengah mengalami fase yang berbedabeda. Dari fase awal ketika Islam tiba di Asia Tengah, Islam pada era kekuasaan Uni Soviet, hingga ketika Asia Tengah menjadi negaranegara merdeka terlepas dari bayang-bayang Soviet. Dalam fase-fase tersebut, relasi Islam dengan negara di mana ia menaunginya tidaklah monolitik, termasuk relasi ulama sebagai otoritas yang paling

tersebut terjadi bukan karena kegagagalan untuk mendidik, juga bukan kegagalan untuk menjaga, melainkan akibat dari kegagalan untuk memahamai relevansi sejarah lima negara bekas pengaruh imperium Rusia tersebut (Kazakhstan, Kirgiztan, Tajikistan, Turkmenistan, dan Uzbekistan). Lihat Jordan Pahl, "Islam in Central Asia: A Religion and a Heritage" (presented at the Young Historians Conference, Portland State University, 2012), 1, diakses pada 25 April 2017, http:// pdxscholar.library.pdx.edu/younghistorians/2012/oralpres/3/. Dalam konteks Indonesia, kajian spesifik tentang Asia Tengah dengan beragam dinamikanya belum banyak dilakukan. Di antara yang langka itu adalah karya Hamka, Islam di Asia Tengah dan karya Agustinus Wibowo, Garis Batas: Perjalanan di Negeri-negeri Asia Tengah (Jakarta: Gramedia, 2011). Selebihnya adalah karya terjemahan ke dalam bahasa Indonesia.

3 Tentang bagaimana peran mereka yang ditutupi oleh kekejaman Monarki Rusia era Ramanov dan seterusnya, bisa dibaca di Muḥammad b. Mūsā al-Sharīf, "Ulamā", Ásiyà al-Wustā (al-Turkistān) bayn al-Mad̄i wa al-Hädìr, n.d., diakses pada 25 April 2017, https://books.islamway.net/1/oqail/alshreef--9.pdf.

4 Edward J. Lazzerini, "Beyond Renewal: The Jadīd Response to Pressure for Change in the Modern Age" dalam Jo-Ann Gross (ed.), Muslims in Central Asia: Expressions of Identity and Change, Central Asia Book series (Durham: Duke University Press, 1992), 152. 
berpengaruh di dalam Islam yang juga mengalami 'pasang-surut'. Relasi pasang-surut tersebut berbanding lurus dengan relasi antara penguasa dengan Islam itu sendiri.

Meskipun pembahasan pasang-surut relasi ulama dan umarā' di Asia Tengah menjadi bagian dari pembahasan ini, namun tulisan ini tidak secara spesifik mengurai persoalan tersebut. Fokus utama tulisan ini adalah terkait dengan asal-usul dinamika ketegangan antara dua kutub ulama yang di dalam artikel ini penulis sebut dengan qadimis dan jadidis, apa yang melatari ketegangan tersebut, dan bagaimana dampak ketegangan tersebut kaitannya dengan dinamika Islam di Asia Tengah.

Tentu saja, untuk mengantarkan diskusi pada fokus utama tersebut, tulisan ini secara singkat akan terlebih dahulu mengurai asalusul dan perkembagan Islam di Asia Tengah dari masa ke masa serta bagaimana peran ulama di wilayah "jalur sutra" perdagangan dan dakwah di masa lampau ini. Tiga poin inilah yang akan menjadi fokus tulisan ini.

\section{Islam di Asia Tengah}

Sebelum Islam masuk, penduduk Asia Tengah menganut beragam agama, seperti Budha, Zoroaster, dan Nasrani. Mereka adalah korban diskriminasi etnis, penindasan, dan perang antara suku-suku dan pasukan militer kekaisaran Cina dari Timur dengan Persia dari Barat.

Tercatat dalam sejarah bahwa Islam masuk ke Asia Tengah pada saat tentara Pembebasan Islam bergerak menuju Asia Tengah di bawah pimpinan Qutaybah b. Muslim pada tahun 712 M. ${ }^{5}$ Namun, sebelum itu, Islam telah memasuki wilayah Asia Tengah (Azerbaijan) pada masa Khalifah 'Umar b. al-Khațtab pada abad ke-1 Hijriah. Tepatnya melalui sahabat Hudhayfah b. al-Yamanī pada tahun $18 \mathrm{H}$ (638 M), kemudian melalui pemimpin pasukannya 'Utbah b. Farqad al-Sulamī yang berhasil membuat kesepakatan damai dengan pendudukan yang terkalahkan. ${ }^{6}$ Pada masa Khalifah 'Umar b. alKhattab pula, Islam meluas tidak saja di Azerbaijan, tetapi juga Armenia, Georgia (Kaukasus Selatan, sebelah barat Laut Qazwin) pada 638-644 M. Sebagaimana juga Islam meluas hingga Khurasan

\footnotetext{
${ }^{5}$ Mas'ūd al-Khawand, al-Aqalliyyāt al-Muslimah fì al-'Ālam: Intishār al-Muslimin fì alDuwal wa al-Buldān ghayr al-Arabiyah wa Ghayr al-Islämiyah (Beirut: Universal Company Publisher, t.th.), 301; Adeeb Khalid, Islam after Communism: Religion and Politics in Central Asia (Berkeley, California: University of California Press, 2014), 25.

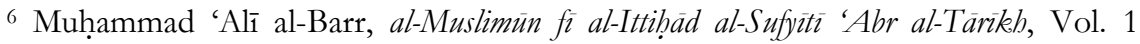
(Jeddah: Dār al-Shurūq, 1983), 37.
} 
yang saat ini terbagi menjadi Turkimanistan Soviet, Iran, dan Afghanistan di bawah tanggung jawab al-Aḥnāf b. Qais. Pada masa khalifah kedua ini pula Islam masuk ke wilayah Dailam dan Thabaristan, pada masa yang sama. ${ }^{7}$

Pada masa kepemimpinan Khalifah 'Uthmān b. 'Affān, tepatnya pada tahun $50 \mathrm{H}(670 \mathrm{M})$, sahabat al-Hakam b. 'Amr al-Ghiffārī menyebarangi Sungai Jihun (Sungai Amu Darya/Oxus) dan membebaskan negara Sogdiana (kini dikenal Uzbekistan). Bahkan, alGhiffārī dikenal sebagai orang pertama yang menyeberangi Sungai Oxus ini. Setelah itu, berlanjut pembebasan-pembebasan kota di wilayah Asia Tengah. 'Ubaid Allāh b. Ziyād berhasil membebaskan Bukhara dan Bikand pada tahun 55 H (674 M), lalu dilanjutkan Sa ${ }^{\top} \overline{1} d$ b. 'Uthmān membebaskan Samarkand. Pada pertempuran dalam pembebasan Samarkand inilah Qatham b. al-'Abbas, paman Nabi Muhammad, syahid di medan perang. Pembebasan-pembebasan ini nyaris tuntas pada masa Mu'āwiyah b. Abī Sufyān. ${ }^{8}$

Dakwah di wilayah ini terus berlanjut pada masa Khalifah 'Uthmān b. 'Affān. Pada masa ini, gerakan dakwah di wilayah Asia Tengah sempat terhenti pada saat terjadinya "konflik besar" dalam Islam (al-fitnah al-kubrâ) antara 'Uthmān b. 'Affān dan 'Alī b. Abī Țālib. Dalam perkembangannya, gerakan pembebasan ini terus dilanjutkan pada Dinasti Umayah dan terus berkembang pada masa pemerintahan 'Abd al-Mālik b. Marwān dan putranya. Pada masa ini, wilayah Asia Tengah menjadi wilayah milik Islam. Pada masa itu, Islam meluas hingga Persia, Azerbaijan, Armenia, Georgia dan wilayah Laut Kaspia yang meliputi seluruh Kaukasus. Pembukaan wilayah Islam dilanjutkan ke wilayah Khurasan, Tabrastan, Sajistan, hingga Kabul.

Panglima besar Qutaybah b. Muslim al-Bahlī adalah pemimpin yang membuka kembali wilayah Khawarizm, Bukhara, Samarkand dan kemudian diikuti dengan Khurasan. Dia menggabungkan wilayahwilayah tersebut dan menerapkan Islam di Transoxiana (mā warä́a alnahr) pada tahun 88 Hijriah/706 M. Selanjutnya dia membawa pasukan hingga ke Cina setelah pembukaan Kashger, ibu kota Turkistan Timur. Pada saat itulah Qutaybah diberi mandat untuk memerintah Provinsi Khurasan oleh al-Hij)àj b. Yūsuf masa

\footnotetext{
${ }^{7}$ Ibid., Vol. 1, 37-38.

8 Ibid., Vol. 1, 37.
} 
pemerintahan Walīd b. 'Abd al-Mālik. Dialah yang berjasa menggerakkan masyarakat untuk berjihad di Transoxiana.'

Pada masa Qutaybah ini pula raja Bukhara memeluk Islam lewat tangannya yang kemudian diikuti oleh masyarakat Bukahara yang berbondong-bondong juga memeluk Islam. Raja kemudian mendakwahkan Islam pada orang-orang Turki yang menjadi mayoritas penduduk wilayah tersebut. ${ }^{10}$ Pada masa itu, negara Islam kokoh berdiri di Turkistan Barat yang saat ini dikenal dengan wilayah Uzbekistan, Turkmenistan, Tajikistan, dan Kyrgistan. ${ }^{11}$

Pada era berikutnya, Islam terus menancapkan kekuatannya di Asia Tengah. Meskipun Dinasti Abbasiyah mulai melemah di Baghdad, keberadaan dinasti-dinasti kecil di wilayah Timur Baghdad, seperti Dinasti Tāāirīyah, Saffarīyah, Samanīyah, dan Ghaznawi hingga Dinasti Saljūq, terus memastikan bahwa Asia Tengah merupakan wilayah Islam yang luar biasa. ${ }^{12}$

Setelah periode ini, Islam juga menyebar ke wilayah yang dikenal dengan Turkistan Timur melalui para sufi. Pada masa itu, tepatnya abad ke-4 Hijriyah (323 H/934 M), Raja Satuq Bughra Khan masuk Islam dan kemudian diikuti oleh jutaan penduduknya. Melalui sang raja itulah, di samping juga pedagang sepanjang sungai Volga, Islam menyebar di Turkistan Timur. Selain itu, Islam juga disebarkan oleh para sufi dan pengikutnya yang terdiri dari para pedagang sepanjang jalur sutra yang memanjang dari Laut Hitam di barat dan China di timur. ${ }^{13}$ Sayangnya, kehadiran bangsa Mongol menjadi mimpi buruk dalam peradaban Islam, termasuk Islam di Asia Tengah. ${ }^{14}$

9 Ibid., 1:37-38; Bandingkan dengan Omar Abd al Hakim, Muslims in Central Asia and The Coming Battle of Islam, n.d., diakses 25 April 2017, https://azelin.files.wordpress.com/2010/08/abu-musab-al-suri-muslims-in-centralasia-and-the-coming-battle-of-islam.pdf.

${ }^{10}$ Abd al Hakim, Muslims in Central Asia.

11 'Ali al-Barr, al-Muslimūna fi al-Ittị̣ād al-S ufyittì, 1:38.

12 Philip Khuri Hitti, History of the Arabs (Jakarta: Penerbit Serambi, 2005), 585-615; Terkait bagaimana kebudayaan Islam berkembangan di Turki, termasuk pada masa kekuasaan Dinasti Saljuq, lihat Syafiq A. Mughni, Sejarah Kebudayaan Islam di Kawasan Turki (Ciputat: Logos, 1997).

13 'Alī al-Barr, al-Muslimūn fì al-Ittihäd al-Sufyìtì, Vol. 1, 38; Penjalasan sekilas perjuangan Sultan Satuq Bughra Khan bisa dilihat di Thierry Zarcone, "Turki dan Asia Tengah" dalam Henri Chambert-Loir dan Claude Guillot (eds.), Ziarah dan Wali di Dunia Islam (Jakarta: Serambi, 2007), 382.

${ }^{14}$ Hitti, History of the Arabs, 615. 
Menurut Lapidus, ${ }^{15}$ sejarah masyarakat Islam di Asia Tengah, sejak periode Mongol sampai periode kontemporer, secara garis besar dibagi menjadi tiga wilayah, yaitu: 1) wilayah padang rumput bagian Barat dan Utara, tepatnya wilayah Golden Horde dan penggantinya, Kazakh; 2) Turkistan yang merupakan pusat Dinasti Timuriyah dan pemerintahan Uzbek pada masa sesudahnya; dan 3) wilayah sebelah Barat Turkistan, yakni daerah perkotaan kabilah di sekitar oasis, yang menjadi provinsi Cina Xinjiang pada akhir abad ke-19.

Peradaban yang berkembang di Mongol pasca runtuhnya Dinasti Abbasiyah, di antaranya timbulnya dinasti-dinasti yang sangat memberikan pengaruh kuat terhadap perkembangan Islam, seperti Dinasti Chagtai, Dinasti Golden Horde, dan Dinasti Ilkhan. Raja Mongol di Turkistan dan Asia Tengah saat itu adalah Baraka, Khan b. Joji, penguasa Mongol pertama yang menyatakan keislamannya. Dia memerintah antara 654-665 H, menyebarkan Islam di Golden Horde dan memenangkan negara di daratan Transoxiana, yang di situ dimulai upaya Hulagu untuk membentuk aliansi dengan negara-negara Nasrani di timur. ${ }^{16}$

Perlahan namun pasti, di tangan Muslim Tartar negeri-negeri seperti Crimea, Bashkir dan Siberia Barat masuk ke dalam kekuasaan Islam. Kota Siberia menjadi bagian ibu kotanya pada abad ke-7 $\mathrm{H}$. Sekitar setengah dari orang Mongolia masuk Islam dan memerintah Asia Tengah hingga Moskow. Wilayah ini berada di bawah kekuasaan Muslim dari Kazan yang segera mereka bangun dan kemudian mereka perintah; negara yang diketahui bernama Uni Soviet, saat itu di bawah kekuasaan Islam. Pemerintahan Timur Lenk berasal dari Polandia dengan ibu kotanya Samarkand.

Singkatnya, Islam berhasil menguasai Asia Tengah sepanjang kurang lebih 240 tahun. ${ }^{17}$ Lapidus menjelaskan bahwa masyarakat Muslim di Asia Tengah dibentuk mengitari tiga serangkai pembagian otoritas, yaitu: otoritas elit suku, elit negara, dan elit agama. Hanya saja, Rusia dan China sebagai sebuah pemerintahan kolonial secara nyata hendak mengubah konfigurasi sejarah ini. ${ }^{18}$

\footnotetext{
15 Ira Marvin Lapidus, Sejarah Sosial Ummat Islam, Vol. 1 dan 2 Jakarta: RajaGrafindo Persada, 2000), 639-642.

16 Clifford Edmund Bosworth, Dinasti-dinasti Islam (Bandung: Mizan, 1993), 167185.

17 'Alī al-Barr, al-Muslimūn fì al-Ittị̣ād al-Ṣufyitì, Vol. 1, 42.

${ }^{18}$ Lapidus, Sejarah Sosial Ummat Islam, 1 dan 2, 670.
} 
Setalah itu, Asia Tengah di bawah kendali Kekaisaran Rusia dan China hingga terjadinya Revolusi Oktober, yang kemudian Kekaisaran Rusia diambil alih oleh penguasa Bolshevik. Tentu saja, rezim komunis yang baru terbentuk tidak membiarkan kawasan Asia Tengah lepas dari cengkeramannya. Mereka menindas masyarakat Asia Tengah bukan karena mereka Uzbek dan Tajik, tapi karena mereka adalah Muslim. Komunis memandang Islam dengan permusuhan dan kecurigaan dan mengampanyekan propaganda sekularisasi. Mereka juga mencoba mengganti identitas dan loyalitas berbasis agama dengan republik yang diciptakan atas dasar etnik. ${ }^{19}$ Uni Soviet berusaha untuk menantang Islam secara intelektual dengan dogma Marxis dan menekan beragam bentuk ekspresi Islam di ruang publik. Sepanjang sejarah Uni Soviet dan hubungannya dengan Islam dan masyarakat Asia Tengah, 'represi nyata dengan cara memaksa orang lain untuk bergabung atau menjadi anggota kelompoknya' (outright repression through co-option) merupakan mekanisme yang digunakan oleh negara. Pasca Perang Dunia II, sentimen Islam terus bertahan di bawah Uni Soviet sebagai negara dan terus berusaha membawa aspekaspek tertentu dari Islam dan mencoba menggabungkannya ke dalam struktur negara. Hal inilah yang menjadikan 'Islam resmi' di Soviet disetujui dan dapat diterima oleh rezim tersebut. ${ }^{20}$

Sebagai bagian kontrol negara terhadap Islam di Asia Tengah, pemerintah Uni Soviet membagi wilayah Asia Tengah menjadi unit administratif yang terpisah. Stalin menciptakan Uzbekistan dan Turkmenistan pada tahun 1924, Tajikistan pada tahun 1929 dan Kazakhstan dan Kyrgyzstan pada tahun 1936. Negara-negara itu diciptakan bukan sebagai tanggapan atas permintaan rakyat, tapi atas perintah Moskow. Soviet memiliki alasan politik yang jelas untuk membentuk apa yang sebelumnya dikenal sebagai Turkistan menjadi lima republik baru. Yang pertama didasarkan pada kebijakan pembagian dan aturan yang jelas. Moskow tidak menginginkan

\footnotetext{
19 Javad Haghnavaz dan Saiedjamaledden Alerasoul, "A History of Islam in Central Asia," American International Journal of Research in Humanities, Arts, and Social Sciences 14 (2014): 128-129, http://iasir.net/AIJRHASSpapers/AIJRHASS14-644.pdf.

${ }^{20}$ Ibid., 129; "Islam resmi" yang dimaksud adalah Islam yang diafirmasi oleh negera. Dalam konteks Soviet, Islam resmi terbentuk atas inisiatif Abdurrahman Rasulaev (seorang mufti Ufa), yang berhasil mendekati Stalin pada akhir 1924 melalui proyek "normalisasi" relasi antara Islam dan pemerintahan Soviet. Lihat Alexandre Bennigsen and Chantal Lemercier-Quelquejay, "'Official' Islam in the Soviet Union” 7, No. 3, Religion in Communist Lands (1979), 148.
} 
terciptanya Turkistan Islam menjadi republik tunggal di bawah Uni Republik Sosialis Soviet. Moskow sangat ganas dalam menangkal semua bentuk identitas Islam yang ada di wilayah ini dan mencari penggantinya dengan usaha untuk membentuk loyalitas kepada republik baru dan ideologi Marxis yang baru dibuat. ${ }^{21}$

Seiring dengan kebijakan Perestroika (retrukturisasi) dan Glasnost (keterbukaan) yang diusulkan Gorbachev pada 6 Maret 1986, ekspresi Islam mulai bangkit di seluruh Uni Soviet. ${ }^{22}$ Kebijakan ini mengendurkan otoritarianisme kaku Uni Soviet dan mengizinkan sedikit ekspresi bebas untuk eksis. Jadi, di republik seperti Uzbekistan, praktik dan sentimen Islam muncul kembali. Di banyak daerah lain di Uni Soviet, seperti Baltik dan Kaukasus, tahun 1980an menghasilkan kebangkitan dalam perasaan nasionalisme. Hal ini juga pararel dengan peningkatan kuantitatif dan kualitatif kajian tentang Islam dan Arab seiring dengan banyaknya pemuda Asia Tengah yang belajar Islam di luar negeri. ${ }^{23}$

Ketika Uni Soviet runtuh pada tahun 1991, negara-negara Asia Tengah memiliki potensi untuk merdeka. Sayangnya mereka tidak secara aktif mencarinya lantaran tidak adanya gerakan nasional yang kuat untuk menggapai kemerdekaan. Tidak ada satu pun negaranegara Asia Tengah yang memiliki sejarah eksistensi nasional sebelum Uni Soviet atau Kekaisaran Tsar. Oleh karena itu, sumber utama loyalitas masyarakat Asia Tengah di bawah Uni Soviet bukanlah negara komunis, melainkan keragaman kesetiaan yang mencakup suku, keluarga, dan tentu saja agama (Islam). Islam memiliki pengaruh yang kuat pada adat istiadat sosial dan identitas. ${ }^{24}$

\section{Ulama di Asia Tengah dan Dinamika Qadimisme versus Jadidisme}

Antara abad ke-7 dan ke-13, sebagaimana dijelaskan Ira M. Lapidus, ${ }^{25}$ institusi historis masyarakat Timur Tengah pra Islam

\footnotetext{
${ }^{21}$ Haghnavaz and Alerasoul, "A History of Islam in Central Asia", 129.

22 The Position of Islam in public life changed further during the Gorbacher years, when his Glasnost policies led, among other things, to a quest for moral and spritual values that were now see to have been corroded by Communism. Lihat Adeeb Khalid, "Ulama and the State in Uzbekistan", Asian Journal of Social Science 42, No. 5 (Januari 1, 2014), 524.

${ }^{23}$ Haghnavaz and Alerasoul, "A History of Islam in Central Asia," 129.

${ }^{24}$ Ibid.

25 Ira Marvin Lapidus, Islamic Societies to The Nineteenth Century: A Global History (Cambridge: Cambridge University Press, 2012), 343.
} 
direkonstruksi dalam bentuk-bentuk Islam. Kerajaan baru dan negara diatur dalam praktik otoritas dan simbol legitimasi Islam. Elit agama Islam, termasuk para ulama dan sufi, berhasil membentuk corak Islami tentang peribadatan, pendidikan, dan administrasi hukum. Mayoritas masyarakat Timur Tengah menjadi Muslim, meskipun dalam praktiknya mereka heterogen. Keragaman praktik berislam itu sangat tergantung dengan di wilayah mana Islam itu tumbuh dan berkembang.

Dalam perkembangannya, sistem institusi Islam dengan beragam budayanya terus bertumbuh di daerah-daerah yang telah mengalami proses Islamisasi di Timur Tengah, termasuk Iran, Transoxania, dan provinsi-provinsi Arab. Dari abad ke-7 sampai abad ke-19, masyarakat Islam, berdasarkan interaksinya dengan budaya lokal dan pengaruh Timur Tengah, juga mulai berkembang di Anatolia dan Balkan, Inner Asia (termasuk juga Asia Tengah), Asia Selatan, dan Asia Tenggara. Sayangnya, pada abad ke-18 dan ke-19, perkembangan sistem global Islam terhalangi oleh keberhasilan Eropa secara ekonomi dan politik. ${ }^{26}$ Kaitannya dengan Asia Tengah, wilayah ini telah menjadi kekuasaan kekaisaran Rusia dan berlanjut pada cengkeraman Uni Soviet.

Perjuangan kemerdekaan masyarakat Asia Tengah tidak terbendung akibat kemarahannya terhadap kaum kolonialis Rusia. Mereka menyalurkan aksi perlawanannya kepada perwakilan pemerintah Moskow di Kazakhstan. Gerakan massa yang memprotes kezaliman Rusia ini selalu dikepalai oleh kalangan "ulama"27 dan sufi. Sebagai contoh adalah pemberontakan kecil yang dikenal dengan Pemberontakan Aftobachi pada tahun 1875-1876 yang dipimpin oleh Makhtum Aftobachi dan gerakan perlawanan yang paling menonjol yaitu pemberontakan di Lembah Farghana tahun 1898 yang dikenal dengan pemberontakan Dukchi Ihsan. ${ }^{28}$ Pemberontakan Dukchi Ibsan

\footnotetext{
${ }^{26}$ Ibid.

27 Thoha Hamim, "Respons Bangsa-bangsa Muslim terhadap Penjajahan Politik Rusia di Asia Tengah", Marâji: Jurnal Ilmu Keislaman, Vol. 1, No. 1 (2014), 195.

${ }^{28}$ Pemberontakan Dukchi Ishan terjadi pada tahun 1898 di Andijan, yang dipimpin oleh Dukchi Ishan. Nama lengkapnya adalah Muhammad-Ali (Madali) Sabir. Diduga kuat bahwa ia lahir pada tahun 1850 atau 1851 di pemukiman Shahidan (dekat Margilan) di Tajik. Di masa mudanya, dia menemani ayahnya ke Samarkand dan Bukhara, di mana dia ditinggalkan bersama para mullah setempat dan mengajarkan dasar-dasar tata bahasa dan pembacaan al-Qur'ān. Ketika berusia sekitar lima belas atau enam belas tahun, dia menjadi murid Syaikh NaqshbandiyaMujaddidiya, Sultan-khan-tura. Lihat Martha Brill Olcott, "Sufsm in Central Asia: A
} 
ini menjadikan pemerintahan Rusia memperlakukan sufisme dengan kecurigaan yang luar biasa. Pemerintah Rusia takut akan munculnya pemberontakan baru di bawah kendali ulama sufi dengan cara melemahkan kelompok sufi secara ekonomi. ${ }^{29}$ Kekuatan sufisme di Asia Tengah ini tampak dari keberadaan makam tokoh Naqshabandīyah, yaitu Bahā’ al-Dīn. Makam Bahā’ al-Dīn seringkali menjadi sasaran kecaman berbagai kelompok. Termasuk di antaranya adalah kalangan Islam ortodoks di mana argumentasi kritiknya diutarakan oleh gerakan reformis Asia Tengah abad ke-19 dan juga oleh rezim Islam resmi zaman Soviet. ${ }^{30}$

Ada dua tahapan dalam sejarah Asia Tengah ketika para sufi aktif secara politik: $:^{31}$ pertama, ketika pengikut sufi menghadapi kekuatan kolonial untuk membebaskan negara mereka. Ini merupakan peran positif meraka. Kedua, ketika mereka berpartisipasi dalam politik nasional dan itu terjadi pada level individu, bukan pada level partai. Peran politik inilah yang menjadikan para sufi bersikap nonkompromis dengan para penjajah serta para penantang ajaran agama Islam. Atas sikapnya yang non kompromis inilah, otoritas Soviet menyebut kelompok persaudaraan sufi ini sebagai kelompok 'Islam tidak resmi' (non-official Islam) dan Islam sektarian. ${ }^{32}$

Dalam konteks Asia Tengah, Islam, tradisi Muslim, dan ulama menjadi sangat penting dalam menilai dan memeriksa situasi di dan sekitar wilayah tersebut. Di Asia Tengah, Islam selalu menjadi salah satu faktor agama dan identitas yang dominan, yang mengatur kehidupan internal dan dalam beberapa hal juga dalam orientasi eksternal di wilayah tersebut, bahkan ketika Asia tengah di bawah pemerintahan Soviet. ${ }^{33}$

Force for Moderation or a Cause of Politicization?," Vol. Number 84 (dipresentasikan pada The Carnegie Papers, Washington DC: Carnegie Endowment for International Peace, 2007), diakses pada 12 Mei 2017, http://carnegieendowment.org/files/cp84_olcott_final2.pdf.

29 Ibid., 13.

30 Thierry Zarcone, "Makam Bahā’ al-Dīn Naqsyaband di Bukhara (Uzbekistan)" dalam Chambert-Loir and Guillot, Ziarah dan Wali, 450.

${ }^{31}$ Farhat Alvi, "The Significant Role of Sufism in Central Asia" 16 (2012), diakses 25 April 2017, http://www.pu.edu.pk/uoc/mag/PDF-FILES/.

32 Ibid.

${ }^{33}$ Seyfettin Erşahin, "The Official Interpretation of Islam under the Soviet Regime: A Base for Understanding of Contemporary Central Asian Islam," Journal of Religious Culture No. 77 (2005), http://web.uni-frankfurt.de/irenik/relkultur77.pdf. 
Dalam perkembangannya, ada fenomena baru dalam dinamika dan peran ulama. Ada perubahan mentalitas dan gerakan yang cukup dramatis di kalangan kelas terdidik Asia pada era abad ke-19 dan awalawal abad ke-20. Jumlah mereka yang terdidik di sekolah gaya Eropa kian meningkat. Mereka-mereka itu yang dalam perkembangannya menjadi benih intelektual sekuler di kemudian hari. Sekolah-sekolah bergaya Eropa itulah yang kemudian memperkenalkan gaya berpikir baru yang turut mewarnai dinamika pemikiran Islam di Asia Tengah. Sementara di pihak lain, kalangan ulama mulai cemas dengan perubahan semacam itu, khawatir identitas Muslim lenyap seiring dengan massifnya identitas Eropa yang diusung oleh para alumni sekolah bergaya Eropa. Hal ini juga mendorong kecenderungan kian bertumbuhnya sikap konservatisme di kalangan para ulama. ${ }^{34}$

Setidaknya, dua kecenderungan itulah yang mewarnai pemikiran Islam modern di Asia Tengah. Dua kecenderungan itu adalah jadidisme dan qadimisme. Istilah jadidisme dan qadimisme merupakan istilah yang populer di wilayah Muslim Soviet, termasuk di antaranya di beberapa wilayah Asia Tengah. Pada mulanya, istilah tersebut mengacu pada perbedaan cara pandang dalam metode pembelajaran dan pengajaran. ${ }^{35}$ Dalam beberapa literatur disebutkan bahwa jadidisme merupakan gerakan reformasi, terutama terkait dengan reformasi sistem pendidikan Islam yang lama, di kalangan intelektual Muslim Asia Tengah, khususnya di Uzbekistan dan Tajikistan, pada pergantian abad ke-19 dan ke-20 dan menghilang pada akhir tahun 1920an, di bawah tekanan rezim Soviet. ${ }^{36}$ Gerakan jadidisme ini tidak saja dibincang di lingkungan akademik Kazakhstan, melainkan melampaui batas terotori wilayahnya.

34 Ahmet Kanlidere, "The Trends of Thought among the Tatars and Bashkirs: Religious Reformism and Secular Jadidism Vs. Qadimism (1883-1910).," Journal of Central Asian \& Caucasian Studies 5, No. 9 (2010), 49, diakses 13 Mei 2017, http://asosindex.com/cache/articles/13767-1.pdf.

35 Mirzahan Egamberdiyev, Yerlan Turgunbayev, and Nurlan Baigarayev, "Jadid Movement in Turkestan in the Late 19 and Early 20 Centuries," World Applied Sciences Journal 29, no. 9 (2014), 1200; K. Hitchins, "Jadidism," in Encyclopaedia Iranica, n.d., diakses 20 April 2017, http://www.iranicaonline.org/articles/jadidism.

36 Hitchins, "Jadidism"; Egamberdiyev, Turgunbayev, and Baigarayev, "Jadid Movement in Turkestan", 1200; Adeeb Khalid menilai bahwa gerakan ini merupakan gerakan yang diusung oleh generasi Muslim pasca kemenangan Rusia atas Asia Tengah. Lihat Adeeb Khalid, "Jadidism in Central Asia: Islam and Modernity in the Russian Empire”, ISIM Newsletter, 2 (1999), 1. 
Ada dua fenomena penting di penghujung abad ke-19 yang melatari munculnya gerakan jadidisme di lingkungan masyarakat Muslim yang berada di bawah bayang-bayang Rusia. ${ }^{37}$ Pertama, siswa Tatar mengalihkan perhatian dari madrasah Bukhara. Di masa lampau, Bukhara dan Samarkand merupakan wilayah yang menjadi magnet para santri kelana untuk mendalami pengetahuan agama. Bukhara dan Samarkand memiliki pengaruh yang luar biasa dalam perkembangan keilmuan keagamaan di wilayah Volga. Bersama rombongan, para pemuda Tatar berkelana dengan semangat pencarian pengetahuan di institusi terkemuka di Bukhara dan Samarkand. Namun, di penghujung abad ke-19 muslim Volga mulai mengambil jarak dengan Bukhara dan mulai belajar di sekolah-sekolah Rusia.

Kedua, mulai ada pengaruh Salafi yang datang dari Mesir dan Hijaz. Khususnya setelah 1890an, gagasan-gagasan Salafisme dari Timur Tengah mulai berhembus ke wilayah Asia Tengah. Hal ini terutama sebagai dampak dari perkembangan media cetak. ${ }^{38}$ Pengaruh salafisme juga terjadi karena para siswa Tatar yang berkelana ke Damaskus, Beirut, Kairo, dan Hijaz. Persentuhan mereka dengan iklim Timur Tengah juga meningkatkan pencerapan mereka akan gagasan-gagasan Salafi.

Dua fenomena penting itulah yang kemudian melatari munculnya tren Islam baru di wilayah Asia Tengah sebagai bagian dari respons terhadap modernitas. Kanlidere menyebutnya, setidaknya ada tiga tren intelektual Islam, yaitu: reformisme religius, jadidisme sekuler, dan reaksi kalangan tradisionalis atau disebut qadimis. ${ }^{39}$ Dari ketiga kecenderungan ini, sesungguhnya bisa disederhanakan menjadi dua kecenderungan besar, yaitu jadidisme yang mencakup reformisme religius dan jadidisme sekuler serta qadimisme.

Reformisme religius merupakan bagian dari gerakan purifikasi dalam Islam. Gerakan ini melanjutkan sepak terjangnya dalam bentuk berbeda, yaitu gerakan jadidisme. Secara garis besar, baik gerakan

\footnotetext{
${ }^{37}$ Kanlidere, "The Trends of Thought among the Tatars and Bashkirs", 50.

38 Ibid., 51-52; Secara khusus, Dudoignon menulis penjelasan terkait dengan bagaimana media cetak di Timur Tengah, khususnya Mesir, menghembuskan angin perubahan di lingkungan Muslim di bawah Imperium Rusia. Lihat, Stéphane A. Dudoignon, "Echoes t Al-Manar among the Muslims of the Russian Empire" dalam Stéphane A. Dudoignon, Hisao Komatsu, and Yasushi Kosugi, eds., Intellectuals in The Modern Islamic World: Transmission, Transformation, Communication, New Horizons in Islamic Studies (London; New York: Routledge, 2006), 85-116.

${ }^{39}$ Kanlidere, "The Trends of Thought among the Tatars and Bashkirs", 51.
} 
reformisme religius maupun jadidisme sekuler memiliki kesamaan visi, yaitu transformasi masyarakat. Gerakan reformisme religius ini mengampanyekan idealisasi Islam Awal yang dikenal dengan salaf. Gerakan ini tidak saja mengadvokasi persoalan pendidikan dan pemikiran keagamaan, melainkan juga mencakup seluruh aspek kehidupan sosial, termasuk status perempuan, reformasi hukum Islam, dan ekonomi. Gerakan ini beranggapan bahwa kemunduran Islam diakibatkan oleh salah paham terhadap apa yang ia sebut sebagai true Islam. Mereka meyakini, dengan cara kembali pada purifikasi keyakinan dan dinamisme salaf, maka keunggulan Islam akan diraih kembali. Dalam konteks ini, reformisme religius sebagai bagian dari jadidisme sama dengan Salafisme atau Wahabisme. ${ }^{40}$

Di pihak yang lain, jadidisme sekuler memperjuangkan ide dan perhatian yang sama, yaitu transformasi masyarakat. Hanya saja, keduanya memiliki perbedaan cara dalam memperjuangkan idenya dalam rangka revitalisasi masyarakatnya. Jika yang pertama menganggap bahwa kemajuan masyarakat Muslim sangat tergantung pada kekuatan akidahnya dan kemundurannya lantaran kemerosotan akidahnya, maka jadidisme sekuler menganggap bahwa kemunduran masyarakat Muslim bukan karena kemerosotan akidahnya melainkan kemunduran dalam hal peradaban.

Para reformasi religius berpandangan bahwa alasan utama kemunduruan masyarakat Muslim adalah kemerosotan keimanan selama beberapa abad terdahulu. Dengan demikian jika orang Muslim hendak merestorasi kekuasaan, kekayaan, dan martabat masyarakat mereka, mereka harus memahami Islam sebagaimana Muslim awal (kaum salaf) menerimanya. Zeki Velidi Togan (1890-1970) menolak pandangan ini. Ia berpandangan bahwa alasan kemunduran bukanlah karena kemerosotan keyakinan agama, melainkan akibat kemunduran umat Muslim dalam peradaban material. Kemunduran peradaban Muslim tersebut berdampak pada kemunduran Islam. Oleh karena itu, seiring dengan keterbelakan material ini, masyarakat Muslim tidak

\footnotetext{
40 Abdulagatov membahas tentang beberapa kesamaan sekaligus perbedaan antara jadidime dan Wahabisme. Lihat Zaid Abdulagatov, "Wahhabism and Jadidism in Islamic Consciousness in Daghestan: Parallels and Contradictions", Central Asia and the Caucasus, No. 6 (42) (2006), diakses 12 Mei 2017, http://cyberleninka.ru/article /n/wahhabism-and-jadidism-in-islamic-consciousness-in-daghestan-parallels-andcontradictions.
} 
akan pernah maju, baik mereka mereformasi keyakinan agama mereka atau memurnikan keyakinan agama mereka). ${ }^{41}$

Untuk mengatasi kemunduran peradaban tersebut, diperlukan pembenahan dalam bidang pendidikan. Kelompok ini mengusulkan apa yang disebut dengan usül-i jadid, metode baru dalam pendidikan dan pengajaran. Isu inilah yang menjadi isu pertama yang melahirkan perdebatan antara jadidisme dan qadimisme yang menjadi tren ketiga sebagaimana kategorisasi yang dibuat Kanlidere.

Perdebatan antara gerakan qadimisme dan jadidisme di Asia Tengah yang berlangsung pada akhir kekuasaan Imperium Rusia dan awal Uni Soviet memikat perhatian para sarjana, baik di Barat, Rusia, maupun di Asia Tengah. Gerakan jadidisme ini disematkan pada mereka yang mengupayakan modernisasi sekolah Islam (maktab dan madrasah) pada masa Imperium Rusia. Para sarjana penganut gerakan jadidisme ini memperkenalkan metode pedagogis baru untuk menyebarkan tradisi literasi, kurikulum sistematik dan kelas sekolah reguler. Jadidisme juga memperkenalkan materi ajar yang biasanya tidak diajarkan di sekolah Islam, seperti matematika, geografi, sejarah, dan ilmu alam. Lebih penting lagi, gerakan jadidisme ini menekankan pengajaran dengan menggunakan bahasa daerah. Dengan program ini, jadidisme bergeser dari sekolah tradisional, yang disebut qadimis, di mana mereka mengritik model pembelajaran dan pelajaran repetitif yang tidak memiliki relevansi dengan modernisasi Rusia yang berlangsung cepat ini. ${ }^{42}$ Pendiri gerakan jadidisme ini adalah intelektual dan guru di Kremia-Tatar, Ismail Gasprinskii (1851-1914) yang pertama kali membuka model baru ini di Bakhchisarai pada 1883, di samping Yusuf Akçura (1876-1936).

Secara sosiologis, kecenderungan munculnya dua pola gerakan ini tidak lepas dari situasi Volga pada akhir abad ke-19. Pada masa itu, situasi ekonomi Volga-Tatar memburuk. Ini dibuktikan dengan kian menurunnya perdagangan antara Volga-Tatar dan Asia Tengah. Akibatnya, penghasilan pedagang Tatar berangsur memburuk. Hal ini ditambah dengan masuknya barang produksi Eropa ke pasar Bukhara dan Kaukasus yang dampaknya akan menggeser produksi lokal. Jika situasi ini dibiarkan, maka Muslim akan kehilangan pangsa pasar yang

\footnotetext{
${ }^{41}$ Kanlidere, "The Trends of Thought among the Tatars and Bashkirs", 56.

${ }^{42}$ Michael Kemper and Shamil Shikhaliev, "Qadimism and Jadidism in TwentiethCentury Daghestan", Asiatische Studien - Études Asiatiques 69, No. 3 (Januari 18, 2015): 593-594, diakses 27 April 2017, http://www.degruyter.com/view/j/asia. 2015.69.issue-3/asia-2015-1009/asia-2015-1009.xml.
} 
telah mereka miliki. ${ }^{43}$ Atas dasar situasi semacam ini, baik Garprinski maupun Akçura meyakini bahwa keterpurukan ekonomi sangat terkait dengan kemunduran dalam perkembangan intelektual. Ini juga ditopang dengan fakta bahwa Muslim Rusia lebih dipengaruhi model pendidikan a la Bukhara abad pertengahan. Keterbatasan akses ekonomi dan keilmuan inilah yang menjadikan situasi intelektual di wilayah Tatar-Volga tidak ramah dengan pemikiran modern. ${ }^{44}$

Faktor itulah yang memicu perdebatan awal antara jadidisme dan qadimisme, yaitu persoalan kegagalan pendidikan di Asia Tengah. Tidak hanya pada persoalan pendidikan dan pengajaran, perdebatan antara dua kubu itu juga masuk para ranah pemikiran keagamaan, yang puncaknya masuk pada ranah advokasi tentang transformasi beragam aspek kehidupan komunal. ${ }^{45}$ Bagi sebagian kalangan, label qadimis dihindari. Mereka enggan disebut sebagai qadimis. Mereka menganggap dirinya sebagai 'penjaga agama' atau orang yang berada di jalan pendahulu yang baik (al-salaf al-sälih). Di pihak lain, jadidis juga menyebut diri mereka sebagai 'orang yang ingin kembali ke jalan salaf. $^{46}$ Artinya, baik qadimis maupun jadidis sama-sama mendaku dirinya sebagai yang berada di jalan para salaf.

Masing-masing, baik qadimis maupun jadidis sama-sama saling menggambarkan lawannya secara negatif. Di satu sisi, jadidis menganggap bahwa qadimis sebagai orang yang berpikiran picik (narrow minded) dan tidak sadar akan perkembangan dunia, di sini yang lain, qadimis menggambarkan jadidis sebagai orang yang berpandangan liberal dalam agama, merusak agama, missionaris, dan stigma negatif lainnya. ${ }^{47}$

Pada dasarnya, kehadiran jadidisme dalam khazanah pemikiran Islam di Asia Tengah tidak lepas dari respons Muslim terhadap modernitas. Jadidisme merupakan istilah lokal yang disematkan pada

\footnotetext{
${ }^{43}$ Kanlidere, "The Trends of Thought among the Tatars and Bashkirs", 49.

44 Ibid.

45 "The revivalist movement in religion and education set out by the Bulgarian Turks, as they known in history, and the Tatars of Kazan, as from the late $18^{\text {th }}$ and early $19^{\text {th }}$ century to 1920 s was called 'Jadidism" İbrahim Maraş, "A Critique of Method in Religious Education in the Post-Bolshevik Revolution Tatar Madrasas: Tradition or Modern?", Journal of Islamic Research I, No. 2 (Desember 2008), 88.; Adeeb Khalid, "Being Muslim in Soviet Central Asia, or an Alternative History of Muslim Modernity", Journal of the Canadian Historical Association 18, No. 2 (2007), 128. 46 Maraş, "A Critique of Method in Religious Education in the Post-Bolshevik Revolution Tatar Madrasas: Tradition or Modern?”, 88.

${ }^{47}$ Ibid.
} 
gerakan reformasi Islam Modernis. Meskipun berakar pada perdebatan mengenai hubungan antara tradisi Islam dan dunia modern yang berkecamuk di seluruh dunia Muslim, jadidisme tetap memiliki kekhasan lokal. Konsep kunci dalam jadidisme adalah "peradaban" (madaniyah) dan "kemajuan" (taraqqi), yang berasimilasi dengan pemahaman mereka tentang Islam untuk menghasilkan interpretasi Islam modern, di mana pencapaian "peradaban" dilihat sebagai kewajiban agama umat Muslim. ${ }^{48}$

Dalam perkembangannya, intelektual atau ulama jadidis mengalihkan fokusnya pada ranah politik dengan berpartisipasi dalam pembangunan dan penyebaran nasionalisme sekuler, terutama setelah Revolusi 1905 ketika mereka merintis penerbitan media cetak (surat kabar dan jurnal) milik umat Muslim, dan ketika para intelektual Muslim dari seluruh penjuru kekaisaran bertemu dalam serangkaian kongres. Beberapa jadidis yang menonjol juga mendapatkan posisi di Duma Rusia pertama. ${ }^{49}$ Keterlibatan dalam ranah politik ini kian mengeruhkan konflik antara jadidisme dan qadimisme.

Seiring terjadinya Revolusi Bolshevik, konflik yang terjadi antara qadimis dan jadidis kian meningkat. Ini dikarenakan perbedaan pandangan tidak lagi bergerak 'horizontal', melainkan menggunakan media kekuasaan pada ranah 'vertikal'. ${ }^{50}$ Sebagaimana dijelaskan Adeeb Khalid, ${ }^{51}$ bahwa Revolusi Bolshevik membuka peluang dan kemungkinan baru bagi kalangan jadidis. Kalau sebelumnya jadidis mengampanyekan gagasannya terbatas hanya pada reformasi sekolah tradisional dan gerakan kultural untuk senantiasa melakukan reformasi, atau meminjam istilah Hitchins sebagai elit intelektual kecil (as a small intellectual elite), ${ }^{52}$ maka seiring gerakan revolusi Bolshevik, ia

48 Khalid, "Being Muslim in Soviet Central Asia, or an Alternative History of Muslim Modernity", 128.

49 Kemper and Shikhaliev, "Qadimism and Jadidism in Twentieth-Century Daghestan”, 594. Duma Negara adalah lembaga legislatif bawah di Rusia. Lembaga ini menggantikan Soviet Tertinggi pada tahun 1993. Nama Duma Negara diambil dari parlemen dalam Kekaisaran Rusia yang dibentuk sebagai akibat revolusi tahun 19051907. Secara formal, Duma Negara adalah badan legislatif. Duma Negara I (bulan April-Juli 1906) dan Duma Negara II (bulan Februari-Juni 1907) dibubarkan oleh pemerintah Tsar. Lihat https://id.wikipedia.org/wiki/Duma_Negara

50 Ira Marvin Lapidus, Sejarah Sosial Ummat Islam, Vol. 3 Jakarta: RajaGrafindo Persada, 2000), 383.

51 Khalid, "Being Muslim in Soviet Central Asia, or an Alternative History of Muslim Modernity", 128.

52 Hitchins, "Jadidism." 
berharap bisa melakukan perubahan melalui jalur struktural, yaitu negara. Oleh karena kaum Bolshevik memiliki agenda radikal transformasi sosial dan budaya mereka sendiri, begitu juga dengan jadidisme, maka kedua elemen ini menemukan tempat di mana mereka bisa bekerja sama. Mereka 'terpaksa' menyesuaikan program dan metode dengan tuntutan politik massa dan perjuangan sosial, danpada saat yang sama-mereka tidak hanya harus menghadapi emir dan ulama konservatif (qadimis), tetapi juga melakukan manuver di antara kekuatan politik Rusia yang bersaing di Tashkent dan kota-kota lainnya. ${ }^{53254}$ Pada masa-masa ini, banyak sekolah kelompok jadidis digabungkan, bahkan diubah, menjadi sekolah Soviet. Guru-guru yang semula mengajar di sekolah kelompok jadidisme difungsikan oleh sekolah-sekolah Soviet. Sementara jenis pengajaran kelompok jadidis digabungkan dengan pendidikan Soviet, pembelajaran a la qadimisme berlanjut secara pribadi, 'ilegal', dan berbeda dengan model pendidikan sekuler Soviet. Ajaran qadimisme disalurkan secara 'underground sepanjang era Soviet. ${ }^{55}$

Berbeda pada masa berikutnya, yaitu era pasca Soviet. Baik qadimisme maupun jadidisme mungkin bertemu, khususnya dalam konteks kultural, termasuk di dalamnya dalam hal pendidikan. Kemper dan Shikhliev menggunakan istilah qadim-jadid patchworks, perpaduan sistem qadimisme dan jadidisme. Sistem campuran ini telah diterapkan di semua universitas Islam di Dagestan pasca Soviet hingga kini. Sementara struktur dan metode pengajarannya diambil dari sistem jadidis, literatur yang digunakan dalam disiplin fiqh, hadìth, tafsir, termasuk juga tasawuf merupakan literatur yang digunakan di lingkungan qadimis. Kebijakan 'peleburan sistem' ini sangat sesuai dengan kecenderungan umum dalam kebijakan Federasi Rusia terkait dengan Islam, yaitu untuk menangkis pengaruh luar (to fend off external

${ }^{53}$ Ibid.; Lihat juga, Kemper and Shikhaliev, "Qadimism and Jadidism in TwentiethCentury Daghestan", 594-595. Banyak intelektual jadidis yang setelah tahun 1917 masih tetap tinggal di Rusia. Mereka yang pertama kali dikooptasi oleh kaum Bolshevik yang saat itu sangat membutuhkan kader Muslim lokal untuk memimpin sekolah dan administrasi, namun kemudian terpinggirkan dan juga dihilangkan secara fisik ketika cukup banyak kader Bolshevik yang siap menggantikannya.

${ }^{54}$ Kalangan jadidis ini berkolaborasi dengan kubu Partai Komunis Rusia lantaran umat Muslim tidak memiliki kekuatan politik untuk dapat merealisasikan tujuan ideologis dan kultural mereka secara independen. Lihat, Lapidus, Sejarah Sosial Ummat Islam, 3:386.

55 Kemper and Shikhaliev, "Qadimism and Jadidism in Twentieth-Century Daghestan", 608. 
influences). Terlebih bahwa jadidisme dalam beberapa hal kerap dikaitkan dengan Salafisme dan Wahabisme, sementara Salafisme sendiri dianggap sebagai infiltrasi berbahaya dari luar negeri. Pada saat yang sama, promosi metode pengajaran qadim dipahami sebagai bagian dari pembelaan 'Islam tradisional'. ${ }^{56}$

Dengan demikian, relasi jadidisme dan qadimisme mengalami pasang surut. Terkadang konflik yang terjadi meningkat, tetapi mungkin saja antara keduanya berjumpa. Semua itu sangat terkait dengan kepentingan dan konstelasi sosio-politik yang berkembang. Konflik yang terjadi antara qadimisme dan jadidisme sesungguhnya lebih sebagai akibat dari ketegangan politik, ketimbang semata-mata persoalan kesenjangan teologis. ${ }^{57}$

\section{Penutup}

Asia Tengah merupakan wilayah Islam yang menyumbangkan investasi intelektual yang luar biasa pada masanya. Ditopang oleh kehadiran Islam yang relatif awal, kota-kota Asia Tengah menjadi wilayah jalur sutra perdangan dan dakwah, di samping juga dalam distribusi keilmuan. Situasi demografis itulah yang turut menopang peta intelektualisme dan perkembangannya di Asia Tengah.

Ulama merupakan elemen penting dalam diaspora Islam dan peradaban Islam di Asia. Merekalah yang terlibat dalam proses diversifikasi ajaran Islam sekaligus berkonstribusi dalam perjuangan melawan kolonialisme. Namun di pihak lain, seiring dengan tantangan modernitas, ulama mengalami relasi pasang-surut dengan sesamanya. Keragaman cara merespons terhadap modernitas melahirkan keragaman cara aktualisasi dalam mengatasi problem sosial masyarakatnya. Munculnya jadidisme yang kemudian mendapat reaksi

\footnotetext{
56 Ibid., 616.

57 Dudoignon, sebagaimana dikutip Kemper dan Shikhlaliev, berpendapat bahwa qadimisme dan jadidisme memiliki banyak kesamaan: keduanya muncul dari sebuah 'pembaharuan etika' umum di kalangan Muslim Volga-Ural sejak paruh kedua abad ke-18. Kedua tren tersebut diuntungkan dari otonomi baru Islam yang diberikan negara Rusia kepada masyarakat Muslim, dan kemudian dari munculnya kelompok sosial pedagang Tatar yang mendukung sekolah dan publikasi jadid dan qadim. Dengan latar belakang ini, Dudoignon menantang perbedaan yang jelas antara qadimisme dan jadidisme di Tatar, historiografi Rusia dan Barat, terutama karena perbedaan ini terlalu sering didasarkan pada gagasan ideologis sejarawan, yang cenderung membuat jadidis menjadi 'lentera positif dan melenyapkan qadimisme lantaran dianggap sebagai musuh akal dan penyelidikan ilmiah. Ibid., 595.
} 
dari qadimisme merupakan fenomena modern Asia Tengah ketika ulama berupaya merespons terhadap modernitas.

Ketegangan yang bermula dari persoalan kultural meningkat eskalasinya ketika ketegangan itu bergeser pada ranah struktural. Namun demikian, ada momentum yang memungkinkan mereka bergandengan tangan, khususnya ketika mereka mendapatkan tantangan sosial dan politik yang sama dan isu yang diusung pun terkait dengan persoalan kultural.

\section{Daftar Rujukan}

Abdulagatov, Zaid. "Wahhabism and Jadidism in Islamic Consciousness in Daghestan: Parallels and Contradictions", Central Asia and the Caucasus, No. 6 (42) (2006), diakses 12 Mei 2017, http://cyberleninka.ru/article /n/wahhabism-and-jadidismin-islamic-consciousness-in-daghestan-parallels-andcontradictions.

Alvi, Farhat. "The Significant Role of Sufism in Central Asia" 16 (2012), diakses 25 April 2017, http://www.pu.edu.pk /uoc/mag/PDF-FILES/.

Barr (al), Muhammad 'Alī. al-Muslimūn fì al-Ittibād al-Sufyìtì 'Abr alTãrikh, Vol. 1. Jeddah: Dār al-Shurūq, 1983.

Bennigsen, Alexandre and Lemercier-Quelquejay, Chantal. "'Official' Islam in the Soviet Union" 7, No. 3, Religion in Communist Lands, 1979.

Bosworth, Clifford Edmund. Dinasti-dinasti Islam. Bandung: Mizan, 1993.

Dudoignon, Stéphane A. "Echoes t Al-Manar among the Muslims of the Russian Empire" dalam Stéphane A. Dudoignon, Hisao Komatsu, and Yasushi Kosugi, eds., Intellectuals in The Modern Islamic World: Transmission, Transformation, Communication, New Horizons in Islamic Studies. London; New York: Routledge, 2006.

Egamberdiyev, Mirzahan., Turgunbayev, Yerlan., and Baigarayev, Nurlan. "Jadid Movement in Turkestan in the Late 19 and Early 20 Centuries," World Applied Sciences Journal, Vol. 29, No. 9 (2014. Hitchins, K. "Jadidism," in Encyclopaedia Iranica, n.d., diakses 20 April 2017, http://www.iranicaonline.org/articles/jadidism.

Erşahin, Seyfettin. "The Official Interpretation of Islam under the Soviet Regime: A Base for Understanding of Contemporary 
Central Asian Islam," Journal of Religious Culture, No. 77 (2005), http://web.uni-frankfurt.de/irenik/relkultur77.pdf.

Haghnavaz, Javad dan Alerasoul, Saiedjamaledden. "A History of Islam in Central Asia," American International Journal of Research in Humanities, Arts, and Social Sciences, Vol. 14, 2014.

Hakim, Omar Abd al. Muslims in Central Asia and The Coming Battle of Islam, n.d., diakses 25 April 2017, https:/ /azelin.files.wordpress.com/2010/08/abu-musab-al-surimuslims-in-central-asia-and-the-coming-battle-of-islam.pdf.

Hamim, Thoha. "Respons Bangsa-bangsa Muslim terhadap Penjajahan Politik Rusia di Asia Tengah”, Maräji: Jurnal Ilmu Keislaman, Vol. 1, No. 1, 2014.

Hamka, Islam di Asia Tengah dan karya Agustinus Wibowo, Garis Batas: Perjalanan di Negeri-negeri Asia Tengah. Jakarta: Gramedia, 2011.

Hitti, Philip Khuri. History of the Arabs (Jakarta: Penerbit Serambi, 2005.

Kanlidere, Ahmet. "The Trends of Thought among the Tatars and Bashkirs: Religious Reformism and Secular Jadidism Vs. Qadimism (1883-1910)", Journal of Central Asian \& Caucasian Studies, Vol. 5, No. 9, 2010.

Kemper, Michael and Shikhaliev, Shamil. "Qadimism and Jadidism in Twentieth-Century Daghestan", Asiatische Studien - Études Asiatiques 69, No. 3, Januari 18, 2015/ diakses 27 April 2017, http://www.degruyter.com/view/j/asia. 2015.69.issue-3/asia2015-1009/asia-2015-1009.xml.

Khalid, Adeeb. "Being Muslim in Soviet Central Asia, or an Alternative History of Muslim Modernity", Journal of the Canadian Historical Association, 18, No. 2, 2007.

Khalid, Adeeb. "Jadidism in Central Asia: Islam and Modernity in the Russian Empire", ISIM Newsletter, 2, 1999.

----. "Ulama and the State in Uzbekistan", Asian Journal of Social Science, Vol. 42, No. 5, Januari 1, 2014.

----. Islam after Communism: Religion and Politics in Central Asia. Berkeley, California: University of California Press, 2014.

Khawand (al), Mas'ūd. al-Aqalliyyāt al-Muslimah fì al-'Alam: Intishär alMuslimin fi al-Duwal wa al-Buldàn ghayr al-'Arabiyah wa Ghayr alIslamiyah. Beirut: Universal Company Publisher, t.th.

Lapidus, Ira Marvin. Islamic Societies to The Nineteenth Century: A Global History. Cambridge: Cambridge University Press, 2012. 
-----. Sejarah Sosial Ummat Islam. Jakarta: RajaGrafindo Persada, 2000.

Lazzerini, Edward J. "Beyond Renewal: The Jadīd Response to Pressure for Change in the Modern Age" dalam Jo-Ann Gross (ed.). Muslims in Central Asia: Expressions of Identity and Change, Central Asia Book Series. Durham: Duke University Press, 1992.

Maḥmūd, Ḥasan Aḥmad. al-Islām fì Asiyà al-Wustạ: bayn al-Fathayn al'Arabì wa al-Turkì. Kairo: al-Hay'ah al-Mișrīyah al-'Āmmah lī alKitāb, 1973.

Maraş, İbrahim. "A Critique of Method in Religious Education in the Post-Bolshevik Revolution Tatar Madrasas: Tradition or Modern?”, Journal of Islamic Research I, No. 2 (Desember 2008.

Mughni, Syafiq A. Sejarah Kebudayaan Islam di Kawasan Turki. Ciputat: Logos, 1997.

Olcott, Martha Brill. "Sufsm in Central Asia: A Force for Moderation or a Cause of Politicization?," Vol. 84 (dipresentasikan pada The Carnegie Papers, Washington DC: Carnegie Endowment for International Peace, 2007), diakses pada 12 Mei 2017, http://carnegieendowment.org/files/cp84_olcott_final2.pdf.

Pahl, Jordan. "Islam in Central Asia: A Religion and a Heritage". Presented at the Young Historians Conference, Portland State University, 2012.

Sharīf (al), Muḥammad b. Mūsā. "Ulamā" Ásiyā al-Wustāa (al-Turkistān) bayn al-Mad̄i wa al-Hạdiri, n.d., diakses pada 25 April 2017, https://books.islamway.net/1/oqail/alshreef--9.pdf.

Zarcone, Thierry. "Turki dan Asia Tengah" dalam Henri ChambertLoir dan Claude Guillot (eds.), Ziarah dan Wali di Dunia Islam. Jakarta: Serambi, 2007. 